\title{
Pemanfaatan Rinfosheet Sebagai Media Informasi Laporan Penjualan Barang Pada Raharja Internet Cafe
}

\author{
${ }^{1}$ Untung Rahardja, ${ }^{2}$ Eka Purnama Harahap, ${ }^{3}$ Dini Intan Pratiwi \\ ${ }^{1,2,3}$ STMIK Raharja \\ untung@raharja.info ${ }^{l)}$ ekapurnamaharahap@raharja.info ${ }^{2}$ dini.intan@raharja.info ${ }^{3)}$
}

\begin{abstract}
ABSTRAK. Raharja Internet cafe (RIC) merupakan tempat pelayanan di Perguruan Tinggi Raharja yang dikhususkan untuk membantu kegiatan perkuliahan Mahasiswa/i Perguruan Tinggi Raharja. Laporan penjualan barang pada RIC merupakan informasi yang sangat dibutuhkan guna kelancaran usaha. Namun RIC masih menggunakan Microsoft Excel dalam melakukan penginputan laporan,yang mana laporan tidak dapat tersimpan secara otomatis sehingga memungkinkan data yang sedang di input hilang, kemudian pada saat akan memberikan laporan penjualan kepada manager harus di cetak/printout terlebih dahulu, tentunya hal ini sangat tidak efektif karena akan mengakibatkan penumpukan kertas. Oleh karena itu, diperlukannya pemanfaatan RinfoApps yaitu RinfoSheet, sebuah fasilitas pengolah angka dan datadimana pengguna dimudahkan untuk membuat dan berbagi data di web dan dapat diakses dimana saja dan kapan saja, baik melalui komputer, smartphone maupun tablet.Dalam penelitian ini, ditemukan 2 (dua) permasalahan pada sistem yang ada sebelumnya dan didukung 4 (empat) metode penelitian yaitu metode observasi, analisa, studi pustaka dan implementasi. Hasil akhir yang di capai dari penelitian ini yaitu pembuatan laporan penjualan bisa dilakukan secara online dan laporanpun akan tersimpan secara otomatis, serta dapat di share sehingga tidak perlu mencetak laporan untuk di berikan kepada manager.
\end{abstract}

Kata Kunci: RIC, RinfoSheet, Laporan

ABSTRACT. Raharja Internet cafe (RIC) is a service place at Perguruan Tinggi Raharja which is dedicated to help the lecture activities of Perguruan Tinggi Raharja Students. Reports on the sale of goods on the RIC is information that is needed for smooth business. But RIC still uses Microsoft Excel to do input reporting, which report can not be saved automatically to enable the data being input is lost, then when will give sales report to the manager must be printed / printout first, of course this is not effective because it will lead to paper buildup. Therefore, it is necessary to use RinfoApps RinfoSheet, a number and data processing facility where users are able to create and share data on the web and can be accessed anywhere and anytime, either via computer, smartphone or tablet. In this research, found 2 (two) problems in the existing system and supported by 4 (four) research method that is observation method, analysis, literature study and implementation. The final result of the research is making the sales report can be done online and the report will be stored automatically, and can be shared so it does not need to print reports to be given to the manager.

Keywords:RIC, RinfoSheet, Reports

\section{PENDAHULUAN}

Dewasa ini teknologi informasi mengalami perkembangan yang sangat cepat mengikuti kebutuhan manusia yang juga terus bertambah. Seiring dengan perkembangan teknologi ini google merupakan salah satu tujuan utama para pengguna internet untuk mendapatkan informasi, diaman google sendiri selalu melakukan inovasi untuk memenuhi kebutuhan pengguna. Salah satu inovasi teknologi informasi google yaitu Google Drive, merupakan tempat di mana kita dapat dengan aman menyimpan file secara online dan mengaksesnya dari mana saja menggunakan web browser standar. Kita bahkan dapat menggunakan komputer, smartphone atau tablet untuk mengakses file di mana saja. Kita juga dapat berbagi file dengan orang lain, sehingga lebih mudah untuk berkolaborasi dengan orang lain dalam mengerjakan tugas. Kita dapat menyimpan foto, video, PDF, dokumen teks, spreadsheet, presentasi dan lain-lain.

Salah satu tools yang dimiliki Google drive yaitu Google Spreadsheetmerupakan salah satu fasilitas pengolah angka dan data Googe docs dimana pengguna dimudahkan untuk membuat dan berbagi data di web dan dapat diakses dimana saja dan kapan saja, baik melalui komputer, smartphone maupun tablet, baik dengan atau tanpa ada koneksi internet sekalipun.

Dalam Perguruan Tinggi RaharjaGoogle Spreadsheet dikenal dengan nama Rinfosheet yaitu salah satu fasilitas yang disediakan didalam Email Rinfo (Gmail yang digunakan sebagai identitas Perguruan Tinggi Raharja). Banyak sekali manfaat atau keuntungan yang disediakan oleh Google Spreadsheet atau Rinfosheet ini salah satunya yaitu dapat melakukan tugas pembuatan laporan keuangan, dimana Rinfosheet ini sering digunakan dalam dunia usaha, terutama usaha kecil menegah untuk pencatatan laporan akuntansi seperti laporan penjualan dan stok barang. Pada Google Spreadsheet atau Rinfosheet Penggunaan formula dan fungsi seperti operasi matematika dan statistik membuat pengolahan data keuangan menjadi lebih mudah 
dilakukan, selain dapat mengurangi kesalahan penghitungan juga memberikan ketepatan dalam hasil penghitungan.

\section{METODE PENELITIAN}

Dalam Penelitian ini terdapat 4 (empat) tahapan yang digunakan, yaitu sebagai berikut:

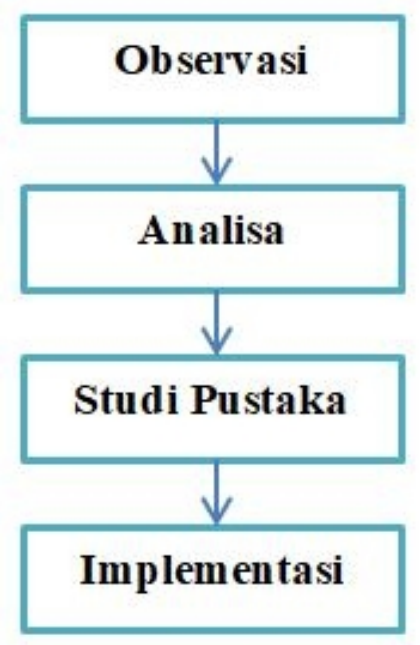

Gambar 1. Metode Penelitian

Keterangan:

1. Metode Observasi atau pengamatan ini dilakukan secara langsung pada Raharja Internet Cafe untuk melihat langsung sistem yang berjalan sebelumnya.

2. Metode Analisa, setelah melakukan observasi selanjutnya yaitu menganalisa sistem pencatatan penjualan pada Raharja Internet Cafe (RIC), dan setelah dianalisa proses pencatatan penjualan di RIC masih berjalan secara offline dengan menggunakan microsoft excel, sehingga proses pencatatan penjualan barang masih kurang optimal.

3. Studi Pustaka

Banyak penelitian yang sebelumnya (literature review) dilakukan mengenai pembahasan tentang pemanfaatan Google Spreadsheet atau Rinfosheet ini. Dalam penelitian pemanfaatan Rinfosheet ini perlu dilakukan studi pustaka sebagai salah satu penerapan metode penelitian yang akan dilakukan juga sebagai bahan acuan untuk memperkuat hasi penelitian. Berikut ini beberapa literature review yang didapakan dan memiliki kolerasi searah dengan penelitian yang akan dibahas dalam jurnal diantaranya adalah sebagai berikut :

a. Penelitian yang dilakukan oleh Untung Rahardja, Khanna Tiara dan Ray Indra Taufik Wijaya pada tahun 2014 dengan judul "Penerapan Rinfo sebagai Media Pendukung Untuk Proses Pembelajaran Pada Perguruan Tinggi Raharja". Penelitian ini menjelaskan bahwa banyak tools yang dapat di manfaatkan dari Rinfo ini semisal Rinfo Docs yang bisa dimanfaatkan untuk menulis dokumen, RinfoSheet untuk membuat spreadsheet, membuat reminder dengan Rinfo Calender, membuat website sederhana dengan dengan Rinfo Sites dan berbagai tools lainnya.

b. Penelitian yang dilakukan oleh Khana Tiara, Erlita Rasdiana dan Nursam Somantri pada tahun 2016 dengan judul "Rinfo Sheet Sebagai Media Penunjang Pembuatan Laporan Untuk Mahasiswa". Dalam penelitian ini peneliti merasa membuat laporan menggunakan Rinfosheet lebih mudah dari pada menggunakan Microsoft Excel karena dapat diakses dan disimpan secara online dan menggunakan Rinfosheet lebih efektif dan efisien karena mengurangi pemakaian kertas karena mahasiswa tidak perlu printout untuk memberikan laporan kepada dosen, mahasiswa hanya perlu invite dosen yang dituju untuk mengkoreksi hasil laporan yang dibuat dan dosen dapat memberikan komentar untuk memperbaiki kesalahan laporan yang telah mahasiswa buat. Sehingga dengan menggunakan Rinfosheet dapat mempermudah mahasiswa membuatan laporan.

c. Penelitian yang dilakukan oleh Indri Handayani, Herrafika Kusumahati dan Alpiah Nurul Badriah pada tahun 2017 dengan judul "Pemanfaatan Google Spreadsheet Sebagai Media Pembuatan Dashboard pada Official Site iFacility di Perguruan Tinggi" dari hasil penelitian ini menunjukan bahwa Google Spreadsheet bisa dimanfaatkan untuk menampung data dan mengolah data untuk 
dijadikan sebuah informasi yang ingin ditampilkan pada Dashboard iFacility. Dengan data yang di peroleh dari Google Form lalu di sortir di Google spreadsheet menggunakan formula atau rumus yang ada pada Google Spreadsheet, kemudian data yang sudah di sortir dalam tabel ditampilkan dalam bentuk grafik atau Google Chart yang merupakan salah satu alat grafik yang di sediakan oleh google yang terdapat di dalam Google Spreadsheet, sehingga Grafik yang di buat melalui Google Spreadsheet merupakan Chart yang digunakan untuk dashboard iFacility.

d. Penelitian yang dilakukan oleh Erna Lovita pada tahun 2013 dengan judul "Application of "Clouds Computing" in Smes Simple Accounting Process For Effective And Efficient Efforts to Penetrate Global Markets". Menjelaskan bahwa terdapat 3 (tiga) kelebihan dengan menggunakan Google Spreadsheet untuk menyusun laporan Keuangan pada UKM (Usaha Kecil Menengah) di indonesia yaitu: (1) UKM tidak perlu menginstall perangkat komputernya dengan software aplikasi khusus melainkan cukup dengan menggunakan Google Spreadsheet yang merupakan fasilitas dari google yang dapat digunakan secara gratis. (2) Data akuntansi dapat di input dari mana saja serta memungkinkan untuk di share ke beberapa pengguna. (3) Data akuntansi yang diolah di Google Spreadsheet tersimpan pada server google secara aman sehingga UKM tidak perlu direpotkan dengan kebutuhan kapasitas memori, virus yang mengganggu serta kemungkinan pencurian data.

Setelah melakukan peninjauan dari keempat literature review yang ada, telah banyak penelitian mengenai RinfoSheet ini, dapat disimpulkan juga dari penelitian di atas bahwa banyak keuntungan yang bisa di manfaatkan dari Rinfosheet ini mulai dari sebagai media pembuatan dashboard, pembuatan laporan, dan juga penyusunan laporan keuangan. Namun saat ini belum ada penelitian yang mengarah pada pemanfaatan Rinfosheet, sebagai media informasi laporan penjualan barang yang dapat memudahkan penginputan laporan harian. oleh karena itu penulis membahas hal "Pemanfaatan RinfoSheet sebagai Media Informasi Laporan Penjualan Barang pada Raharja Internet Cafe" agar bisa memudahkan dalam pencatatan dan pelaporan.

4. Implementasi

Pada penelitian ini sudah di lakukan Implementasi dengan menerapkan RinfoSheet sebagai media informasi laporan penjualan barang pada Raharja Internet Cafe (RIC).

\section{ANALISA PERMASALAHAN}

Raharja Internet Cafe (RIC) merupakan salah satu fasilitas yang diberikan kepada Mahasiswa Perguruan Tinggi Raharja untuk membantu kegiatan perkuliahan pada kampus Perguruan Tinggi Raharja, dengan menyediakan kebutuhan seperti : Up Grade iPad, Instal software terbaru untukiPad, Aksesoris iPad dan Laptop, service, dan kebutuhan lainnya. RIC memfasilitasi mahasiswa Perguruan Tinggi Raharja dengan ruangan yang nyaman, printing, scant dan Sistem Informasi Student (SIS).

Dikutip dari Jurnal SEMNASTEKNOMEDIA ONLINE 3, no. 1 (2015) bahwa Penjualan merupakan suatu sistem keseluruhan dari kegiatan usaha yang ditujukan untuk merencanakan, menentukan harga, mempromosikan dan mendistribusikan barang, jasa, ide kepada pasar sasaran agar dapat mencapai tujuan organisasi. Definisi lain dari penjualan dikutip dari Jurnal Ilmiah Teknologi Informasi Asia 10, no. 2 (2016) bahwa penjualan adalah suatu transaksi yang bertujuan untuk mendapatkan suatu keuntungan, dan merupakan suatu jantung dari suatu perusahaan.

Pada awalnya proses pencatatan laporan penjualan barang pada RIC masih manual yaitu menggunakan Microsoft Excel. Permasalahan yang terjadi saat melakukan penginputan laporan penjualan barangmenggunakan Microsoft Excel ini yaitu pertama laporan tidak tersimpan secara otomatis sehingga memungkinkan data yang sedang di input hilang, contohnya saja saat sedang melakukan penginputan laporan PC tiba-tiba saja mati atau restart maka laporan yang sedang diinput akan hilang karena tidak tersimpan secara otomatis. Kedua pencatatan laporan menggunakan Microsoft Excel tidak dapat di shareatau dibagikan secara online dan hanya dapat dilihat oleh orang yang memiliki file tersebut sehingga untuk memberikan laporan tersebut kepada atasan harus di printout terlebih dahulu akibatnya banyak penumpukan kertas dan mengakibatkan kerugian baik dari segi waktu dan tenaga.

\section{HASIL DAN PEMBAHASAN}

Dari permasalahan yang telah dijabarkan di atas, dimana pembuatan laporan penjualan barang pada RIC masih berjalan secara offline maka dengan pemanfaatan RinfoSheet atau Google Spreadsheet pada Raharja Internet Cafe (RIC) pembuatan laporan bisa secara online yang terhubung melalui Rinfo/Gmail sehingga informasi mengenai laporan yang akan disampaikan bisa menjadi lebih efisien dan modern dimana pengerjaan siklus akuntasi mulai dari pencatatan sampai dengan penyusunan laporan dengan memanfaatkan Rinfosheet yang mendukung Penggunaan formula dan fungsi seperti operasi matematika dan 
statistik membuat pengolahan data menjadi lebih mudah dilakukan, selain dapat mengurangi kesalahan penghitungan juga memberikan ketepatan dalam hasil penghitungan.

Penjabaran prihal pembahasan penelitian dapat dilihat pada Mind Mapping, seperti yang ada dibawah ini.

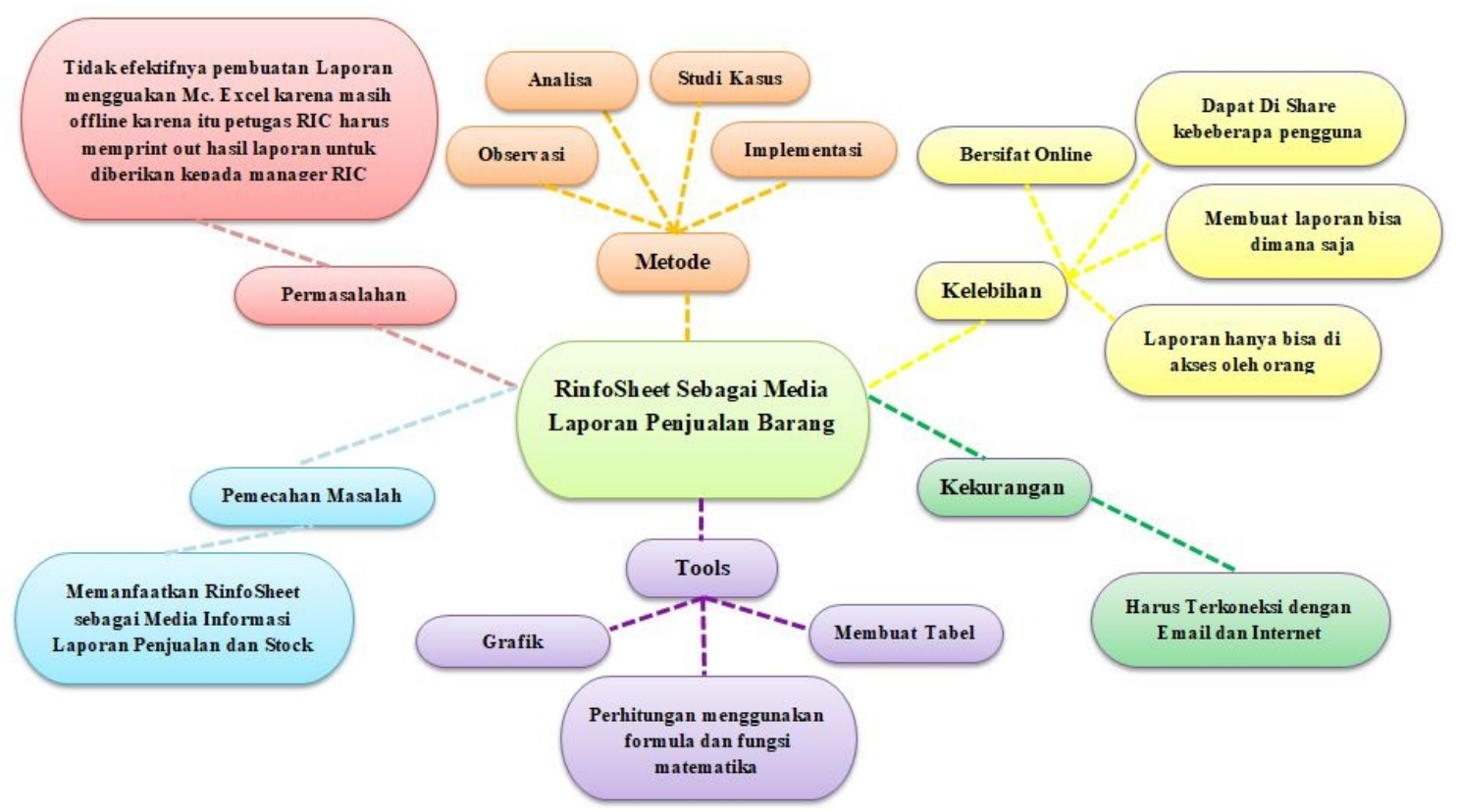

Gambar 2.Mind MappingRinfosheet sebagai media laporan penjualan barang

Di dalam Mind Mapping diatas menghasilkan beberapa penjelasan yaitu kelebihan dari RinfoSheet adalah bersifat online, dapat di share kebeberapa pengguna, membuat laporan bisa di mana saja dan laporan hanya bisa diakses oleh orang tertentu saja. Sedangkan kekurangan dari RinfoSheet adalah harus terkoneksi dengan internet. Tools yang dapat di manfaatkan pada RinfoSheet yaitu Membuat Grafik, Tabel, dan prhitungan menggunakan formula dan fungsi matematika. Permasalahan yang terjadi yaitu tidak efektifnya pembuatan laporan mengguakan Microsoft Excel karena masih offline karena itu petugas RIC harus memprintout hasil laporan untuk diberikan kepada manager RIC. Pemecahan Masalahnya yaitu memanfaatkan RinfoSheet sebagai Media Informasi Laporan Penjualan dengan menggunakan metode observasi, analisa, studi kasus dan implementasi.

\subsection{Pemodelan}

Pemodelan dalam penelitian ini yaitu dengan mendeskripsikan penggunaan RinfoSheet kedalam Flowchart dan Use Case.

\subsubsection{Flowchart Login Rinfo}

Flowchart adalah penggambaran secara grafik dari langkah-langkah dan urut-urutan prosedur dari suatu program (Menurut Adelia 2011:116). "Flowchart adalah penggambaran secara grafik dari langkahlangkah dan urut-urutan prosedur dari suatu program". Dengan adanya flowchart bisa menolong analyst dan juga programmer dalam memecahkan masalah untuk segmen-segmen yang lebih kecil dan dalam menganalisis alternatif-alternatif lain dalam pengoperasian. Flowchart ini biasanya akan mempermudah penyelesaian dari suatu masalah yang perlu di evaluasi dan di pelajari lebih lanjut. 


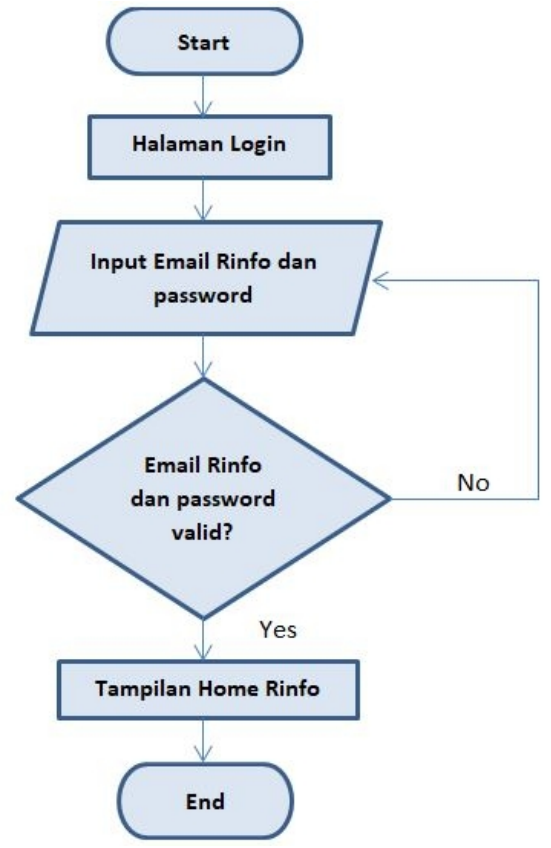

Gambar 3.Flowchart Login Rinfo

Berdasarkan gambar flowchart diatas dapat dijelaskan bahwa untuk login Rinfo yang pertama di lakukan yaitu mengakses halaman login yaitu pada http://gmail.com. Setelah berada dihalaman login selanjutnya mengisi Email Rinfo dan password apabila email Rinfo dan password benar maka akan berhasil masuk ke tampilan home Rinfo dan apa bila Email Rinfo dan password salah maka akan tetap berada pada halaman login dan diusulkan untuk mengisi kembali akun (Email Rinfo dan Password) dan jika sudah benar dan berhasil login maka akan masuk ke Tampilan Home Rinfo/Gmail.

\subsubsection{Use CaseDiagram}

Sri Mulyati (2018) Use Case Diagram merupakan kumpulan diagram dan text yang saling bekerja sama untuk mendokumentasikan bagaimana user (aktor) berinteraksi dengan sistem.

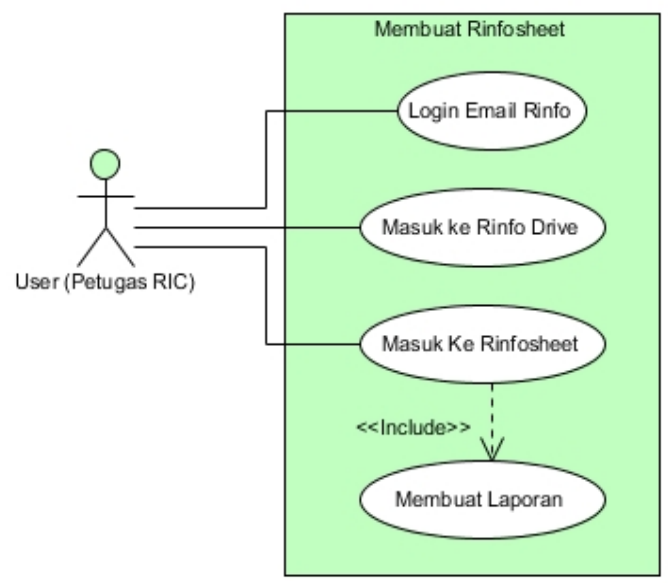

Gambar 4. Use Case Membuat Laporan Pada RinfoSheet

Gambar 4. merupakan gambar use case membuat RinfoSheet dimulai dari user melakukan login emailRinfo pada http://gmail.com setelah berhasil login kehalaman home Rinfo user memilih menu google App pilih RinfoDrive setelah itu pilih menu new dan selanjutnya pilih RinfoSheet dan akan masuk ke halaman RinfoSheet 


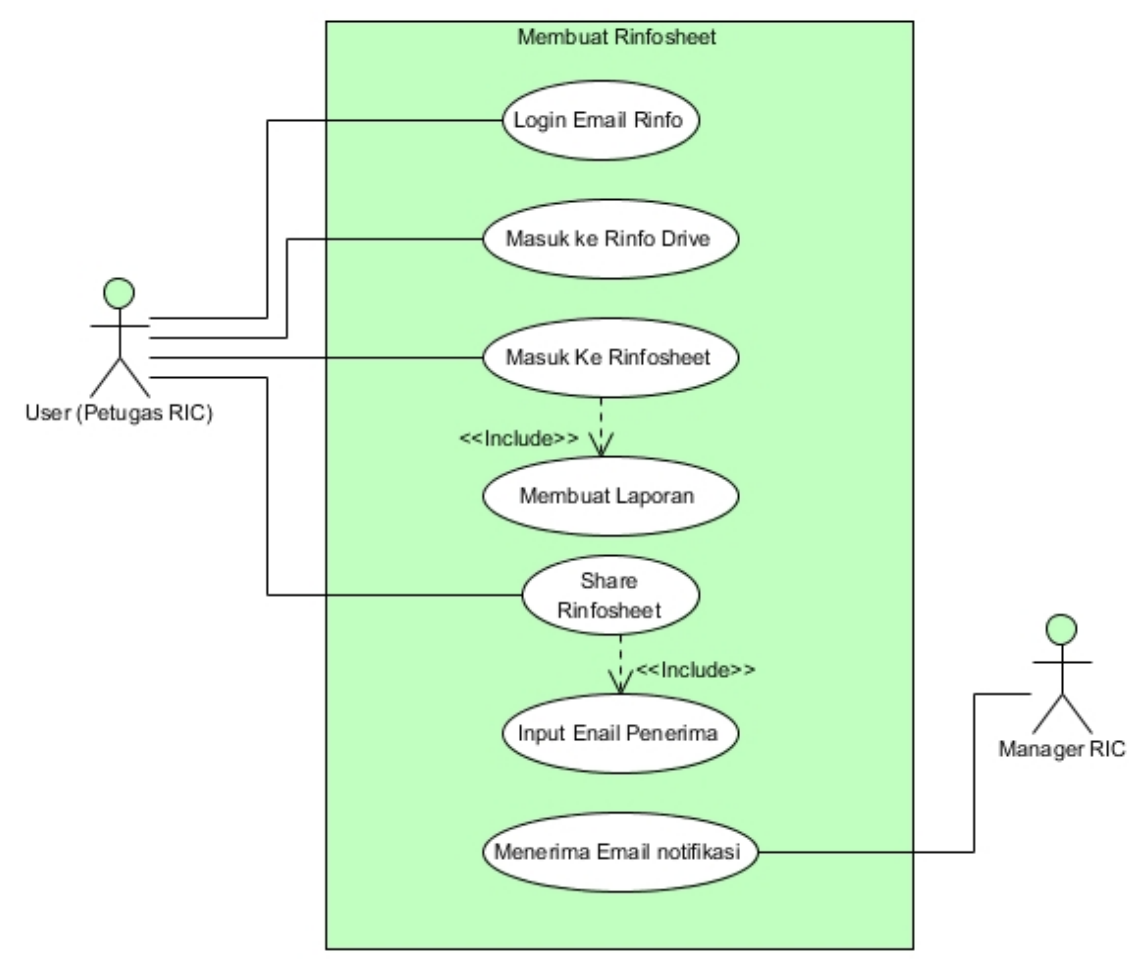

Gambar 5. Use Case Share Laporan

Gambar 5. merupakan gambar use case yang menjelaskan proses share laporan yang ada pada RinfoSheet. Di mana proses awal dimulai dari pembuatan laporan prosesnya sama seperti Gambar 5 di atas. Setelah selesai membuat laporan bisa secara langsung untuk share laporan dengan cara pilih menu share selanjutnya masukkan alamat email tujuan yang akan dituju (Manager RIC) atau orang yang akan menerima laporan dan selanjutnya Manager RIC atau penerima laporan akan mendapatkan notifikasi berupa email yang menyatakan konfirmasi jika sudah di invite.

\subsection{Hasil Pengujian (Implementasi)}

a. Tampilan Halaman Login Pada RinfoSheet

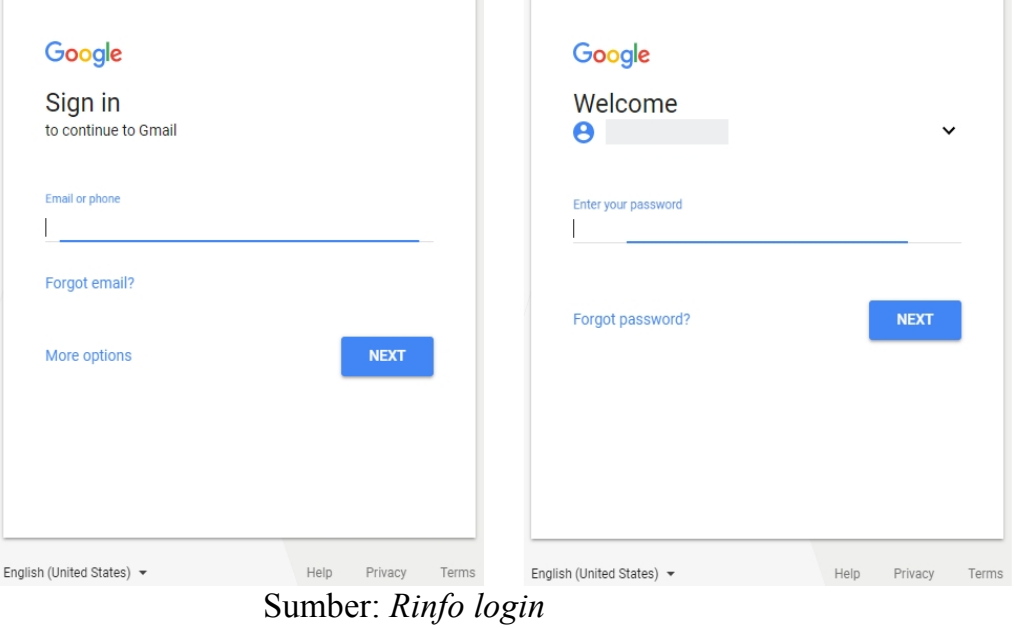

Gambar 6.Tampilan Halaman Login Pada Rinfo

Halaman login Rinfosheetyang dapat di akses pada http://gmail.com. Pada halaman login ini terdapat 2 (dua) tahapan saat login Rinfo, pada tahap pertama berisikan kotak dimana kita diminta untuk memasukkan Email Rinfo atau nomor telepon jika sudah klik Next lalu akan tampil tahapan kedua yang berisikan kotak password dan masukkan password. 
b. Pengujian Tampilan Halaman RinfoSheet

Sumber: RinfoSheet

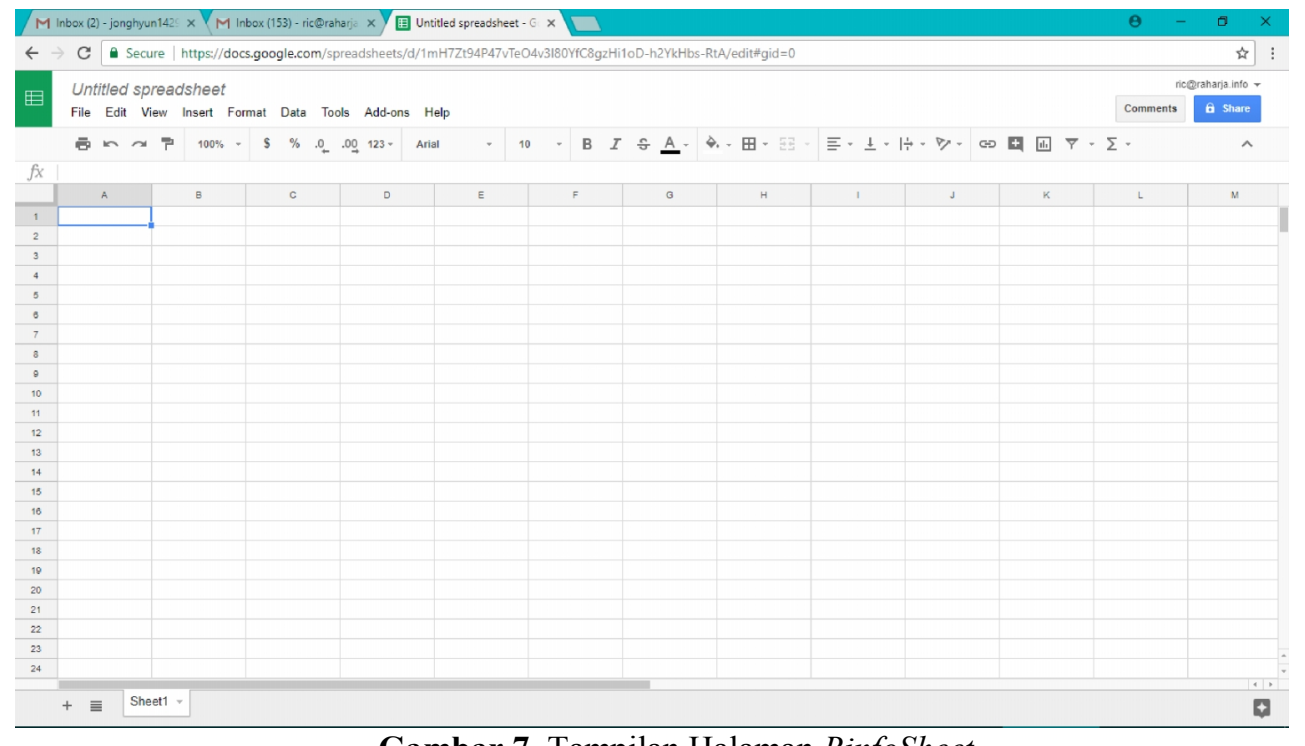

Gambar 7. Tampilan Halaman RinfoSheet

Tampilan Rinfosheet tidak jauh berbeda dengan tampilan spreadsheet pada Microsoft Excel, yaitu pada baris diberi label nomor atau angka (1, 2, 3, 4, dan seterusnya) sementara pada kolom diberi label dengan (A, B, C, D, dan seterusnya). Namun terdapat juga perbedaan yaitu pada tampilan icon yang digunakan sebagai pengaturan tampilan dan tulisan, pada Rinfo hanya terdapat sedikit icon dibanding dengan MicrosoftExcel. Selain itu pada tampilan RinfoSheet ini tidak terdapat buttom Save karena semuanya disimpan secara otomatis saat mengetik.

c. Pengujian Penggunaan Rumus Pada RinfoSheet

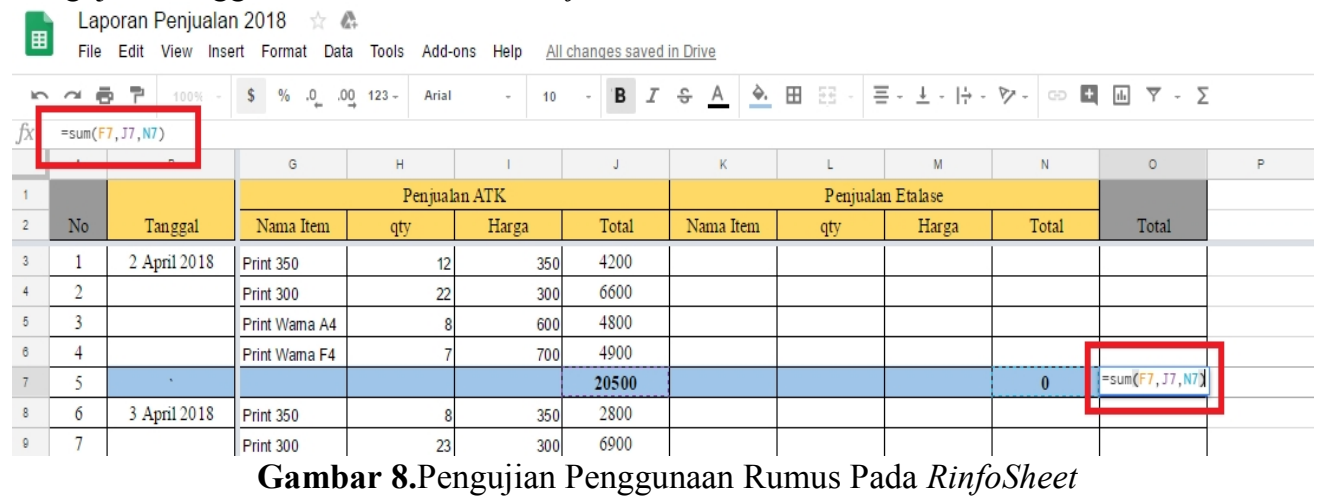

Rumus adalah bagian terpenting dalam pembuatan laporan pada RinfoSheet. Karena setiap tabel dan dokumen yang di kerjakan pada Rinfosheet selalu berhubungan dengan rumus dan fungsi matematika. Operasi fungsi matematika yang sering di gunakan pada RinfoSheet adalah:

Tabel. 1 Operasi Matematika

\begin{tabular}{c|l}
\hline Lambang & \multicolumn{1}{|c}{ Fungsi } \\
\hline+ & Penjumlahan \\
\hline- & Pengurangan \\
\hline$*$ & Perkalian \\
\hline$/$ & Pembagian \\
\hline$\%$ & Persentase \\
\hline
\end{tabular}

Berikut daftar Rumus yang bisa digunakan pada RinfoSheet 
Tabel 2.Rumus/Fungsi matematika pada RinfoSheet

\begin{tabular}{c|l|l}
\hline \multicolumn{1}{c|}{ Rumus/Fungsi } & \multicolumn{1}{c|}{ Keterangan } & \multicolumn{1}{c}{ Penulisan } \\
\hline SUM & $\begin{array}{l}\text { Menjumlahkan pada } \\
\text { angka pada sel atau } \\
\text { range }\end{array}$ & $\begin{array}{l}\text { =SUM(nomor 1,nomor 2,...) } \\
=\text { SUM(sel awal:sel akhir) }\end{array}$ \\
\hline AVERAGE & $\begin{array}{l}\text { Menampilkan rata-rata } \\
\text { dari suatu range data } \\
\text { numerik }\end{array}$ & $\begin{array}{l}\text { =Average (nomor 1,nomor 2,...) } \\
=\text { Average(sel awal:sel akhir) }\end{array}$ \\
\hline SUMIF & $\begin{array}{l}\text { Menjumlahkan data } \\
\text { yang bersifat numerik } \\
\text { dalam suatu range data } \\
\text { dengan kriteria tertentu }\end{array}$ & =SUMIF(range,criteria,sum_range) \\
\hline
\end{tabular}

d. Pengujian Hasil Laporan dalam bentuk Chart dalam Rinfosheet

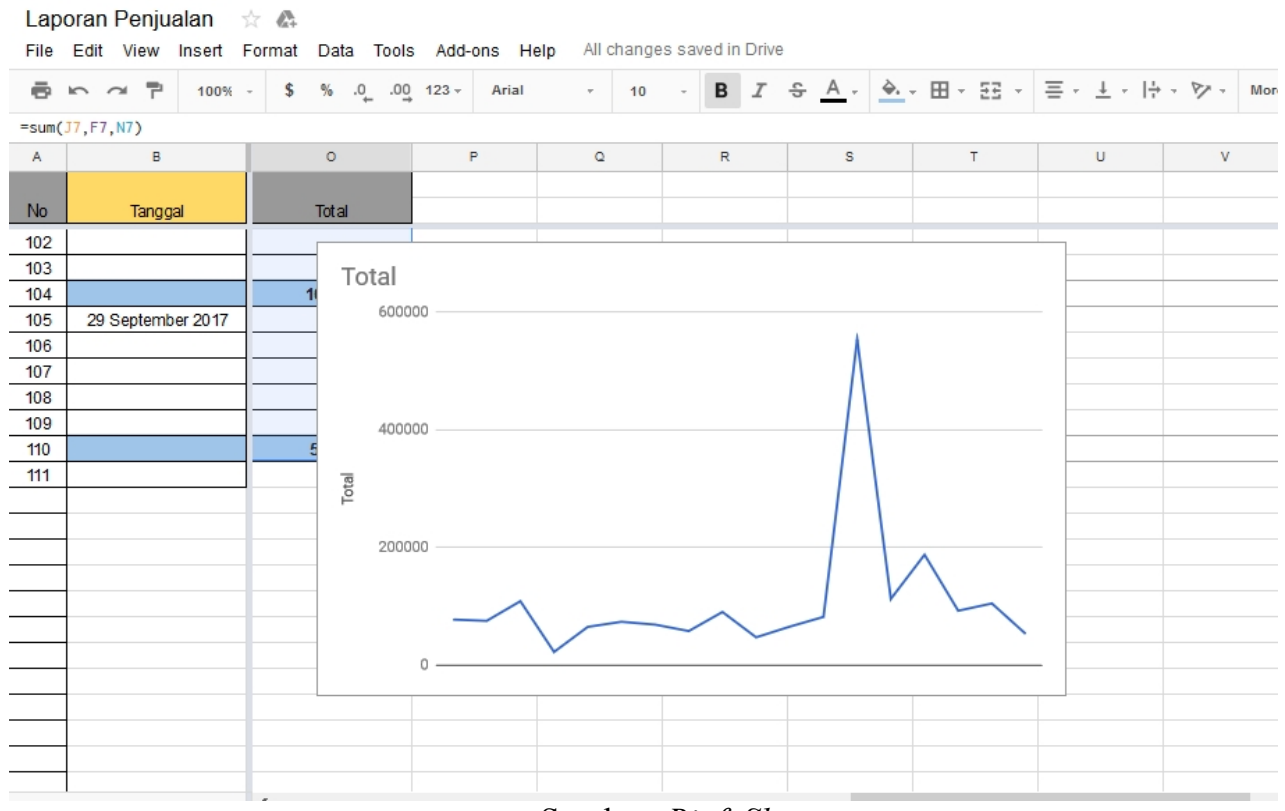

Sumber: RinfoSheet

Gambar 9. Tampilan Hasil Laporan dalam bentuk Chart dalam Rinfosheet

Manfaat lain yang didapatkan dngan mengguanakn RinfoSheet yaitu dapat menampilkan laporan dalam bentuk chart. Gambar di atas merupakan tampilan laporan dalam bentuk chart. Karena pada Rinfosheet dapat menampilkan chart jadi pada saat akhir bulan dapat menampilkan chart penjualan dalam satu bulan. Pada gambar di ataspun dapat dilihat grafik total penjualan dalam sebulan. 
e. Pengujian Share Laporan pada RinfoSheet

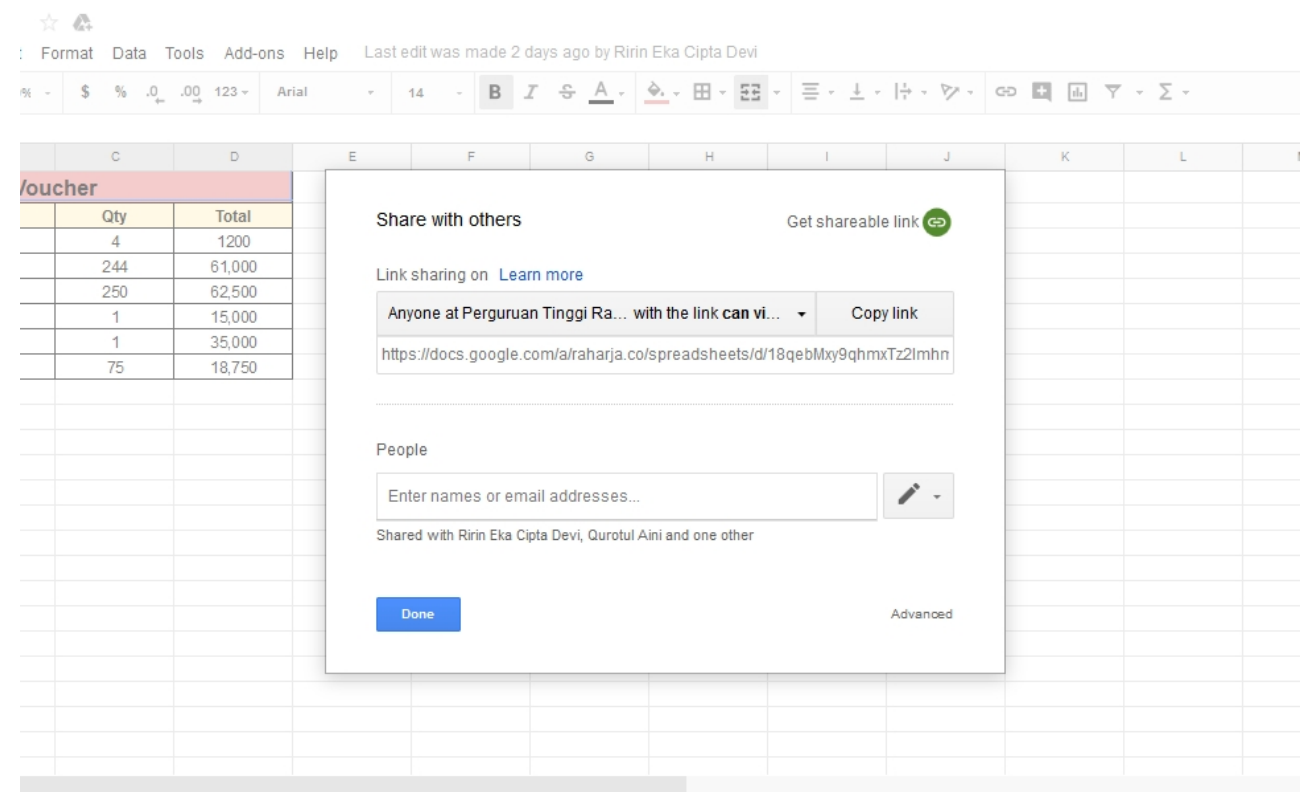

Sumber : Rinfosheet

Gambar 9. Tampilan Share Laporan pada RinfoSheet

Gambar di atas merupakan tampilan RinfoSheet pada saat akan share laporan. Terdapat sebuah kotak isian yang berfungsi untuk menginput email tujuan yang akan diberikan hak ases dari laporan RinfoSheet, sharing file laporan ini bisa dilakukan untuk lebih dari satu orang. Dalam share laporan ini terdapat 3 (tiga) hak akses yaitu can edit, can comment dan can view. Dimana hak akses can edit yaitu orang yang kita share laporan RinfoSheet ini dapat melakukan perubahan/edit pada laporan, can commen hanya dapat memberkan komentar pada RinfoSheet dan can view hanya dapat melihat laporan saja.

\subsection{Pencapaian}

1. Dengan adanya implementasi ini proses pencatatan laporan penjualan barang pada Raharja Internet Cafe (RIC) dapat di lakukan secara online, dan bisa dilakukan dimana saja dan kapan saja, baik menggunakan komputer, smartphone maupun tablet.

2. Dengan adanya implementasi ini staff RIC tidak perlu khawatir jika saat penginputan laporan tiba-tiba $P C$ yang digunakan mati karena dengan menggunakan RinfoSheet akan otomatis ter-save.

3. Dengan adanya implementasi ini staff RIC tidak perlu lagi memberikan laporan kepada manager dalam bentuk kertas, karena dengan fasilitas sharefile yang dimiliki RinfoSheet staff RIC hanya perlu menambahkan email penerima di file yang akan di share.

\section{KESIMPULAN}

Dapat disimpulkan bahwa pemanfaatan RinfoSheet ini bisa sangat bermanfaat bagi pencatatan laporan akuntansi. Pembuatan laporan menggunakan RinfoSheet ini lebih efektif di bandingkan dengan Microsoft Excel karena dapat diakses dan di simpan secara online jadi tidak perlu khawatir saat penginputan laporan dan tiba-tiba $P C$ atau komputer mati karena dengan menggunakan RinfoSheet akan tersimpan secara otomatis. Pembuatan laporan bisa dilakukan dimana saja dan penginputan transaksi pun bisa setiap saat.

Dengan menggunakan RinfoSheet juga memungkinkan untuk menshare laporan jadi saat akan memberikan laporan bulanan ke manager tidak perlu lagi untuk mencetak hasil laporan dengan Rinfosheet hanya perlu menshare laporan dengan menginputkan email tujuan dan saat share laporan terdapat juga pilihan akses yaitu edit, view dan comment. Tools lain yang ada pada Rinfosheet dan bisa dimanfaatkan yaitu membuat laporan dalam bentuk Grafik dan Chart yang sangat bermanfaat untuk mengukur grafik penjualan harian, mingguan, bulanan dan bahkan tahunan. 


\section{DAFTAR RUJUKAN}

Anggraini, E. Y., Wibowo, A., \& Dewi, L. P. (2017). Aplikasi Penjadwalan Tugas berbasis Mobile Device Didukung Google Task dan Google Drive. Jurnal Infra, 5(1), 107-111.

Rahardja, Untung, Khanna Tiara, dan Ray Indra Taufik Wijaya. 2014. "Penerapan Rinfo Sebagai Media Pendukung Untuk Proses Pembelajaran Pada Perguruan Tinggi Raharja”. Jurnal CCIT Vol.8 No.1 September 2014. ISSN: 1978 - 8282. Tangerang : Perguruan Tinggi Raharja

Khanna Tiara, Erlita Rasdiana, and Nursam Somantri. "Penerapan RinfoSheet Sebagai Media Penunjang Pembuatan Laporan Untuk Mahasiswa." Technomedia Journal 1.1 (2016): 36-49.

Handayani, Indri, Herrafika Kusumahati, Alpiah Nurul Badriah "Pemanfaatan Google Spreadsheet Sebagai Media Pembuatan Dashboard pada Official Site iFacility di Perguruan Tinggi" Jurnal Ilmiah SISFOTENIKA, Vol. 7, No. 2, Juli 2017, 177-186.

Yulianto, Y., Alfiah, F., Harahap, E. P., Pahad, B. A., Andriyanto, A., Azhari, I. A., \& Saputra, R. S. (2015). Analisa Peranan Teknologi Internet Sebagai Media Transaksi E-Commerce Dalam Meningkatkan Perkembangan Ekonomi. SEMNASTEKNOMEDIA ONLINE, 3(1), 4-1.

Prasetyo, A., \& Susanti, R. (2016). Sistem Informasi Penjualan Berbasis Web Pada PT. Cahaya Sejahtera Sentosa Blitar. Jurnal Ilmiah Teknologi Informasi Asia, 10(2), 1-16.

Lovita, Erna "Application of "Clouds Computing" in Smes Simple Accounting Process For Effective And Efficient Efforts to Penetrate Global Markets" Journal \& Proceeding Vol 2, No 1 (2012)

Adelia, dan Jimmy Setiawan. 2011. Implementasi Customer Relationship Management (CRM) pada Sistem Reservasi Hotel berbasisi Website dan Desktop. Bandung: Universitas Kristen Maranatha. Vol. 6, No. 2, September 2011:113-126.

Sri Mulyani. 2017. Analisis dan Perancangan Sistem Informasi Manajemen Keuangan Daerah: Notasi Pemodelan Unified Modeling Language (UML). Bandung: Abdi Sistematika. 